\title{
Nitrogen fertilization on intercropping of lettuce and rocket
}

\author{
Aurélio P Barros Júnior; Arthur B Cecílio Filho; Bráulio Luciano A Rezende; Diego RQ Pôrto; Renato de \\ M Prado \\ UNESP-FCAV, Rodov. Prof. Paulo D. Castellane, s/n, 14884-900 Jaboticabal-SP; rutra@fcav.unesp.br; aureliojr02@yahoo.com.br
}

\begin{abstract}
The work was carried out at UNESP, Jaboticabal, São Paulo State, Brazil, from September to December 2006, to evaluate the effect of nitrogen fertilization on intercropping of lettuce and rocket. The experiment was conducted in a randomized complete block design, with four replications, treatments being arranged in a $4 \times 4+2$ factorial design. The treatments were the result of a combination of four $\mathrm{N}$ rates for lettuce $\left(0,65,130\right.$ and $\left.195 \mathrm{~kg} \mathrm{ha}^{-1}\right)$ and four $\mathrm{N}$ rates for rocket $\left(0,65,130\right.$ and $\left.195 \mathrm{~kg} \mathrm{ha}^{-1}\right)$, plus two additional treatments, which corresponded to lettuce and rocket under single cropping. Veronica (lettuce) and Folha Larga (rocket) were the cultivars used. An increase in the $\mathrm{N}$ rate for both cultures, under intercropping system, caused fresh matter gains and higher yields for lettuce and rocket, maximizing the land equivalent ratio (1.84) at $127 \mathrm{~kg} \mathrm{ha}^{-1}$ of $\mathrm{N}$ for lettuce and $195 \mathrm{~kg} \mathrm{ha}^{-1}$ of $\mathrm{N}$ for rocket.
\end{abstract}

Keywords: Lactuca sativa, Eruca sativa, cultivation system and nutrition.

\section{RESUMO}

\section{Adubação nitrogenada em consórcio de alface e rúcula}

O trabalho foi conduzido na UNESP, Jaboticabal-SP, de setembro a dezembro de 2006, com objetivo de avaliar o efeito da adubação nitrogenada em consórcio de alface e rúcula. O delineamento experimental foi de blocos casualizados completos, com quatro repetições, sendo os tratamentos arranjados em esquema fatorial $4 \times 4+2$. Os tratamentos resultaram da combinação de quatro doses de $\mathrm{N}$ para a alface $\left(0,65,130\right.$ e $\left.195 \mathrm{~kg} \mathrm{ha}^{-1}\right)$ e quatro doses de $\mathrm{N}$ para a rúcula $(0$, 65,130 e $195 \mathrm{~kg} \mathrm{ha}^{-1}$ ), mais dois tratamentos adicionais, correspondentes aos monocultivos de alface e rúcula. As cultivares utilizadas foram Verônica (alface) e Folha Larga (rúcula). O aumento da dose de $\mathrm{N}$ para ambas as culturas, em consórcio, proporcionou incrementos na massa fresca e produtividade de alface e da rúcula e maximizou o índice de eficiência de uso da área $(1,84)$ na dose $127 \mathrm{~kg} \mathrm{ha}^{-1}$ de $\mathrm{N}$ para a alface e $195 \mathrm{~kg} \mathrm{ha}^{-1}$ de $\mathrm{N}$ para rúcula.

Palavras-chave: Lactuca sativa, Eruca sativa, sistema de cultivo e nutrição.

\section{(Recebido para publicação em 6 de maio de 2009; aceito em 7 de junho de 2011)}

\section{(Received on May 6, 2009; accepted on June 7, 2011)}

$\mathrm{T}$ he major concern in research is to create technology for rational use of natural resources and agricultural chemicals to produce healthier food with less environmental impact and consequently, a more sustainable productive system. One of the available technologies that may help to carry out this work philosophy is intercropping where two or more species are planted in the same area.

Horticulture is one of the agricultural segments that can benefit from the use of this practice because production is characterized by the intensive use of renewable and nonrenewable resources. Vegetable intercropping might also contribute to sustainable agriculture or one with less environmental impact (Rezende, 2004).

The effective advantage of an intercropping system compared to single cropping is more evident when the involved crops have different requirements for the available resources, either in quality, quantity or demand period. Thus intercropping efficiency depends on the complementariness among the crops involved (Vandermeer, 1981).

One of the aspects of intercropping that has been little studied is the fertilization of the involved crops. The nutritional requirements of the species may change as a result of interaction. According to the literature, authors use nutrient rates recommended for the single cropping of the most demanding vegetable when planting the intercropping system. Side dressing is applied either only for the vegetable considered the main crop in the intercropping system (Oliveira et al., 2004; Barros Júnior et al., 2005), or separately for each vegetable in the intercropping system (Cecílio Filho \& May, 2000; Costa et al., 2007). In both cases, fertilization recommendations in the literature are adopted for the crops cultivated alone, that is, single cropping.

Nitrogen is an outstanding nutrient because of the morpho-physiological alterations it causes in vegetables. Qualitatively it is the most important nutrient for their development and is present in the dry matter in greater quantity than any other element considered (Engels \& Marschner, 1995).

Studies were not found in the Brazilian or international literature regarding nitrogen fertilization for intercropped lettuce and rocket. However there are studies that show positive responses of lettuce (Lédo et al., 2000; Pereira et al., 2003; Mantovani et al., 2005; Resende et al., 2005) and rocket (Ahmed et al., 2000; Ceylan et al., 2002; Purquerio, 2005) to nitrogen fertilization.

The $\mathrm{N}$ requirement for the crops is not known in intercropping so that it is not yet known whether fertilizer should be applied to each crop in the intercropping system, or to only one, and in what quantity. There is also the issue of possible shading of one crop over another that may modify, for better or worse, the metabolism of this crop compared to its standard in single cropping.

Thus the objective of the present 
study was to assess the effect of nitrogen rates for lettuce and/or rocket in an intercropping system on the species growth and yield and the land efficiency ratio.

\section{MATERIAL AND METHODS}

The experiment was carried out in the field from September 26 to December 2, 2006, in UNESP, Jaboticabal Campus $\left(21^{\circ} 15^{\prime} 22^{\prime \prime} \mathrm{S}, 48^{\circ} 18^{\prime} 58^{\prime \prime} \mathrm{N}\right.$ and $575 \mathrm{~m}$ altitude).

The soil in the experimental area was a typical Red Eutroferric Latossol with a heavy clay texture, A moderate caulinitic-oxydic, with gently rolling to rolling relief (Embrapa, 1999). The soil chemical analysis showed $\mathrm{pH}\left(\mathrm{CaCl}_{2}\right)$ $5.6 ; 22 \mathrm{~g} \mathrm{dm}^{-3}$, organic matter $147 \mathrm{mg}$ $\mathrm{dm}^{-3} \mathrm{P}$ (resin) and the following were obtained in mmol $_{c} \mathrm{dm}^{-3}: 5.8 ; 40$ and 16 $\mathrm{K}, \mathrm{Ca}$ and $\mathrm{Mg}$, and $67 \mathrm{~V} \%$.

A complete randomized block design was used with four replications and the treatments were arranged in a 4 $x 4+2$ factorial design. The treatments were the combination of four $\mathrm{N}$ rates for lettuce $\left(0,65,130\right.$ and $\left.195 \mathrm{~kg} \mathrm{ha}^{-1}\right)$ and four $\mathrm{N}$ rates for rocket $(0,65$, 130 and $195 \mathrm{~kg} \mathrm{ha}^{-1}$ ), plus two further treatments, corresponding to lettuce and rocket under single cropping. The rates used in the treatments where based on recommendations by Trani et al. (1997) of 130 and $160 \mathrm{~kg} \mathrm{ha}^{-1}$ of $\mathrm{N}$ for lettuce and rocket, respectively. The rates (treatments) were the same for the two cropping systems (single cropping and intercropping system).

The $2.88 \mathrm{~m}^{2}(1.2 \times 2.4 \mathrm{~m})$ experimental unit was set up for 40 lettuce plants, cropped in $0.30 \times 0.25$ $\mathrm{m}$ spacing and the rocket, in single cropping, in $0.25 \times 0.05 \mathrm{~m}$ spacing, in a total of 192 plants. In the intercropping system, the rocket was sown in furrows located halfway between the lettuce rows. In this cropping system the lettuce was considered the main crop and the rocket the secondary crop.

Lime was applied to raise the base saturation to $80 \%$, using calcinate limestone, with PRNT $=120 \%$. The plots were then prepared. At planting, $50 \mathrm{~kg} \mathrm{ha}^{-1}$ of $\mathrm{K}_{2} \mathrm{O}$ and $200 \mathrm{~kg} \mathrm{ha}^{-1}$ of
$\mathrm{P}_{2} \mathrm{O}_{5}$ were applied to all the experimental units, based on the soil analysis for the lettuce and rocket crops, using potassium chloride and simple superphosphate as sources. For N, when pertinent (nitrogen was not applied to the control), 30.8\% of the $\mathrm{N}$ rates of the treatment were applied at planting and the rest as side dressing; the quantity was divided equally and applied at 10, 20 and 30 days after transplant (DAT) for lettuce and 7, 14 and 21 days after sowing (DAS) for rocket (Trani et al.,1997).

The lettuce, Veronica cultivar, was sown on September 26, 2006, on 288-well expanded polystyrene trays with Plantmax $\mathrm{HA}^{\circledR}$ as substrate. The seedlings were transplanted on October 30, 2006, when they presented four leaves. The rocket, Folha Larga cultivar, was sown on the same day as the lettuce transplant directly in the plot and thinned at 10 DAS for proper spacing between plants in the row.

The weeds were controlled twice by hand hoeing. Fifteen days after setting up the experiment imidacloprid insecticide was sprayed twice to control thysanoptera and aphids. Spray irrigation was carried out according to the crop needs.

The rocket was harvested on November 30, 2006, (31 DAS) and the lettuce on December 2, 2006, (33 DAT). The following were assessed: green matter of the lettuce plants located in the external and internal rows $\left(\mathrm{g} \mathrm{plant}^{-1}\right)$, lettuce yield $\left(\mathrm{kg} \mathrm{ha}^{-1}\right)$, rocket green matter $\left(\mathrm{g} \mathrm{m}^{-1}\right)$, rocket yield $\left(\mathrm{kg} \mathrm{ha}^{-1}\right)$ and the land efficiency rate (LER) proposed by Willey (1979).

The four plant rows, excluding the first and last plant from each row, were considered as useful plot in the assessment of the agronomic traits of the lettuce, in single cropping or the intercropping system. In the assessment of the rocket agronomic traits, in single cropping, the useful plot consisted of the two central rows, excluding 0.30 $m$ from both ends of every row. In the intercropping system, the three rocket rows between the lettuce rows were assessed without considering the first and last $0.30 \mathrm{~m}$ of each row.

Analysis of variance was carried out by the F test, following the proposed design, using the Estat statistical program, of the Department of Exact Sciences at UNESP, Jaboticabal campus. In the analysis, for the traits of each crop, a 4 x $4+2$ factorial design was considered (additional treatment for the lettuce or rocket in single cropping). However, a quadratic polynomial surface response study was carried out regardless of whether there was significant interaction of these factors in the analysis of variance, which when significant ( $F$ test $p<0.05$ ), was used to study the factor interaction. The Statistica program was used to make the graphs and the SAS program for the other analyses.

\section{RESULTS AND DISCUSSION}

There was significant difference between the single cropping (control) and intercropping systems (factorial)

Table 1. Fresh weight of indoor plants of lettuce (MFPI) and external lettuce (MFPE), lettuce yield (PA), fresh weight of rocket (MFR) and yield of rocket (PR) according to the single cropping and the intercropping (massa fresca de plantas internas de alface (MFPI) e externas de alface (MFPE), produtividade de alface (PA), massa fresca de rúcula (MFR) e produtividade de rúcula (PR) em função do monocultivo e dos consórcios). Jaboticabal, UNESP, 2008.

\begin{tabular}{|c|c|c|c|c|c|}
\hline \multirow{3}{*}{ Treatment } & \multicolumn{3}{|c|}{ Lettuce } & \multicolumn{2}{|c|}{ Rocket } \\
\hline & MFPI & MFPE & \multirow{2}{*}{$\begin{array}{c}\text { PA } \\
\text { (kg/ha) }\end{array}$} & \multirow{2}{*}{$\begin{array}{l}\text { MFR } \\
(\mathrm{g} / \mathrm{m})\end{array}$} & \multirow{2}{*}{$\begin{array}{c}\text { PR } \\
\text { (kg/ha) }\end{array}$} \\
\hline & \multicolumn{2}{|c|}{ (g/plant) } & & & \\
\hline Single cropping & $312.80 \mathrm{a}^{2}$ & $290.31 \mathrm{a}$ & $26,486.88 \mathrm{a}$ & $606.44 a$ & $16,010.08 \mathrm{a}$ \\
\hline Intercropping $^{1}$ & $229.88 b$ & $234.94 b$ & $20,446.77 b$ & $569.88 \mathrm{a}$ & $11,283.42 b$ \\
\hline
\end{tabular}

${ }^{1}$ Factorial $4 \times 4$ : $\mathrm{N}$ rates lettuce and $\mathrm{N}$ rates rocket. 2 Means in column followed by different letters differ significantly by $\mathrm{F}$ test at $1 \%$ probability (fatorial 4 x 4 : doses de $\mathrm{N}$ alface e doses de $\mathrm{N}$ rúcula. ${ }^{2}$ Médias na coluna seguidas por letras distintas diferem significativamente pelo teste $\mathrm{F}$ a $1 \%$ de probabilidade). 


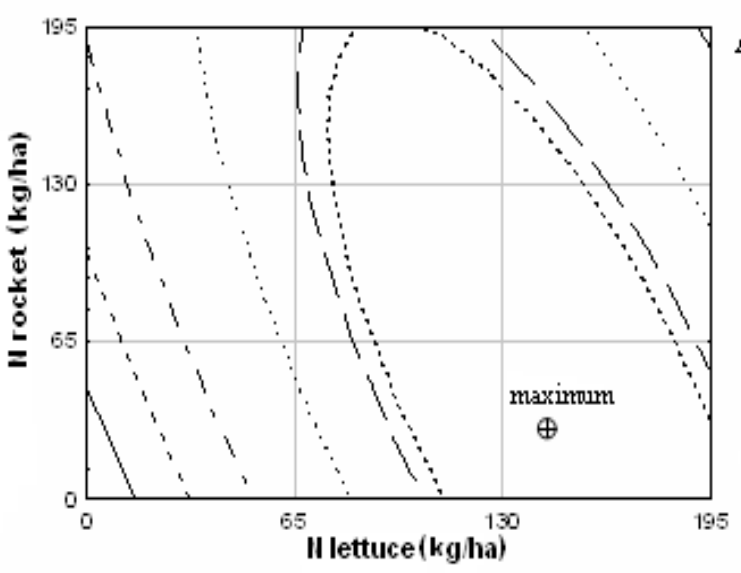

$z=151.172812+1.407334 x+0.491805 y-0.004457 x^{2}-0.002883 x y-0.00068 y^{2}$

$\mathrm{R}^{2}=0.77 *$

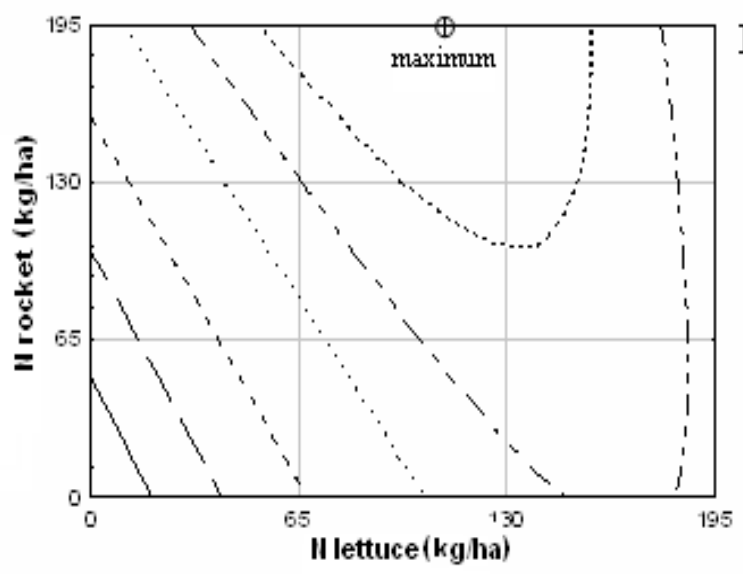

$\mathrm{z}=117.21262+1.72545 \mathrm{x}+0.644527 \mathrm{y}-0.005228 \mathrm{x}^{2}-0.003251 \mathrm{xy}-0.000347 \mathrm{y}^{2}$

$\mathrm{R}^{2}=0.95 * *$

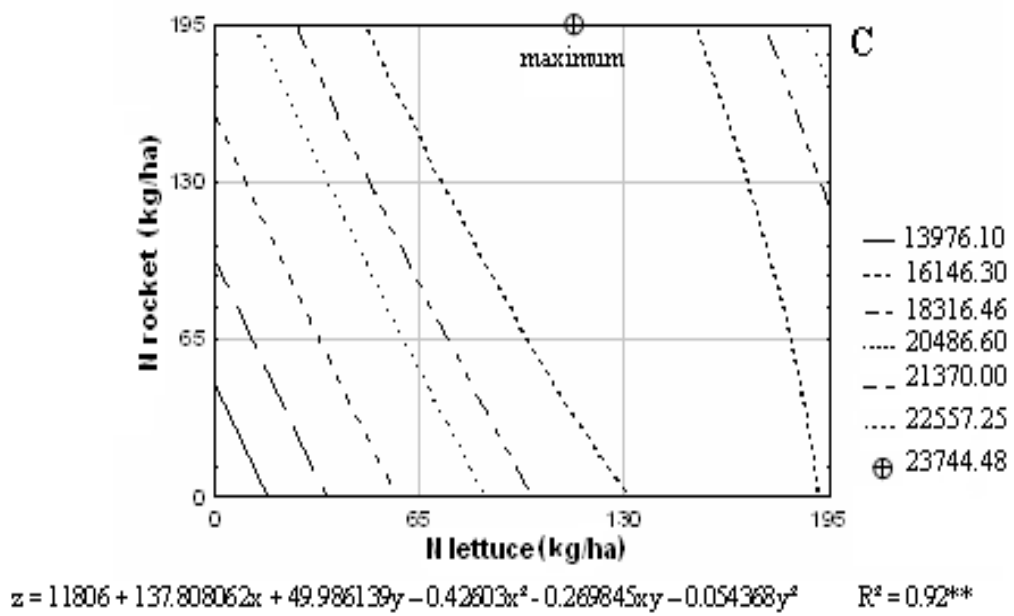

C

$-147.98$

-.. 178.74

- 209.50

.... 240.26

$-258.00$

.... 272.34

$\oplus 286.67$

Figure 1. Response surface isolines for the fresh matter of inside (A) and outside plants (B), and lettuce yield $(C)$ under intercropping, for nitrogen rates in the fertilizers applied to lettuce and rocket (isolinhas da superfície de resposta para massa fresca de plantas internas (A) e externas (B) e produtividade de alface (C) em consórcio, em função das doses de nitrogênio nas adubações de alface e de rúcula). Jaboticabal, UNESP, 2008.

for all the lettuce traits assessed and the values were higher in single cropping than in intercropping (Table 1). This result was attributed to the lack of intraspecific competition in single cropping. Another factor that may explain the higher single cropping values was that in this type of statistical analysis, single cropping was compared to the intercropping mean (factorial system), consequently low values such as the combination of $0 \mathrm{~kg} \mathrm{ha}^{-1}$ $\mathrm{N}$ in lettuce with $0 \mathrm{~kg} \mathrm{ha}^{-1} \mathrm{~N}$ in rocket contributed to the decreased in the factorial mean.

The rocket $\mathrm{N}$ rates influenced almost all the traits, but effect was not observed on the lettuce green matter of plants located on the central rows of the plot (MFPI). The interaction of the factors influenced the assessed traits. There was significant interaction for the land efficiency rate (LER) between the control (single cropping) and the factorial (intercropping systems). For MFPI and for plants on the plot border (MFPE) we observed superiority of the single cropping in comparison to the intercropping (factorial), in 36.1 and $26.6 \%$, respectively. These results were different from those reported by Costa (2006) who did not observed difference in lettuce green and dry matter in single cropping and intercropping with rocket. Lettuce yield in single cropping $\left(16,010.08 \mathrm{~kg} \mathrm{ha}^{-1}\right)$ was $41.9 \%$ greater than that of the intercropping system $\left(11,283.42 \mathrm{~kg} \mathrm{ha}^{-1}\right)$.

Quadratic polynomial surface responses to nitrogen rates were fitted for all lettuce traits assessed.

The maximum green matter value of the lettuce plants $\left(263.06 \mathrm{~g} \mathrm{planta}^{-1}\right)$ on the central rows (MFPI) was obtained with $144 \mathrm{~kg} \mathrm{ha}^{-1}$ of N applied to the lettuce crop and with $43 \mathrm{~kg} \mathrm{ha}^{-1}$ of $\mathrm{N}$ applied to the rocket (Figure 1A). The maximum value obtained in intercropping was $15.9 \%$ less than the MFPI of the single cropping (312.81 g plant $^{-1}$, Table 1). If only the $130 \mathrm{~kg} \mathrm{ha}^{-1}$ of $\mathrm{N}$ applied to the lettuce single cropping are considered, the intercropping system would have an MFPI of $258.80 \mathrm{~g} \mathrm{plant}^{-1}$, that is, $98.4 \%$ of the maximum. Thus the contribution of the fertilization for rocket to the lettuce MFPI was very small.

To obtain $95 \%$ ( $\left.249.9 \mathrm{~g} \mathrm{plant}^{-1}\right)$ of the maximum MFPI, lettuce fertilization in intercropping should be approximately $105 \mathrm{~kg} \mathrm{ha}^{-1}$ without fertilization for rocket. The rate of approximately $82 \mathrm{~kg}$ $\mathrm{ha}^{-1}$ for lettuce was sufficient to obtain 


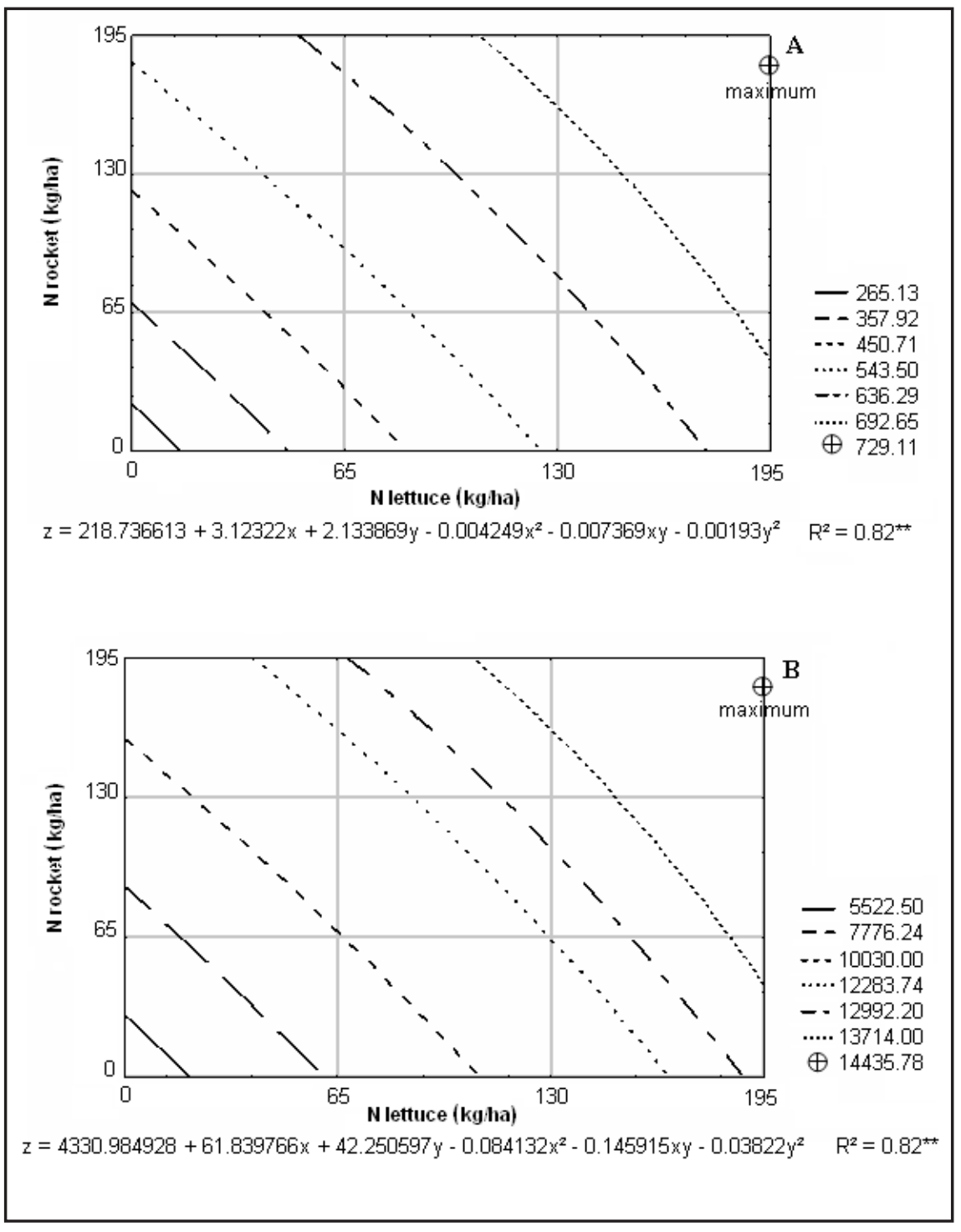

Figure 2. Response surface isolines for the fresh matter (A) and rocket yield (B) under intercropping, for nitrogen rates in the fertilizers applied to lettuce and rocket (isolinhas da superfície de resposta para massa fresca (A) e produtividade de rúcula (B) em consórcio, em função das doses de nitrogênio nas adubações de alface e de rúcula). Jaboticabal, UNESP, 2008 .

$90 \%$ of the maximum MFPI $(236.75 \mathrm{~g}$ plant $^{-1}$ ) without fertilization for rocket (Figure 1A). When $\mathrm{N}$ fertilization was not applied to either crop, the lettuce MFPI in intercropping decreased by $42.5 \%$ compared to the maximum MFPI obtained in intercropping (Figure 1A) and by $51.7 \%$ compared to the MFPI of plants in single cropping (Table 1).

The fertilization was more efficient when the $\mathrm{N}$ was applied to lettuce for the maximum MFPE (286.67 $\left.\mathrm{g} \mathrm{plant}^{-1}\right)$ that can be obtained by fertilizing the intercropping system with $104 \mathrm{~kg} \mathrm{ha}^{-1}$ for lettuce and $195 \mathrm{~kg} \mathrm{ha}^{-1} \mathrm{~N}$ for rocket (Figure 1B). This maximum value a very small quantity of $\mathrm{N}\left(3 \mathrm{~kg} \mathrm{ha}^{-1}\right)$ which needs not to be applied.

Without $\mathrm{N}$ fertilization for either crop, an MFPE of $117.21 \mathrm{~g} \mathrm{plant}^{-1}$ was estimated, that is, a $59.1 \%$ reduction from the maximum obtained (Figure 1B).

The MFPI and MFPE results were similar to those reported by Mantovani et al. (2005), who also observed quadratic fit of the cultivars for lettuce plant green matter in response to increase in the $\mathrm{N}$ rate. The authors obtained the maximum $533 \mathrm{~g} \mathrm{plant}^{-1}$ for the Veronica cultivar, at the rate of $830 \mathrm{mg}^{-1}$ pot $^{-1}$ of $\mathrm{N}$ that corresponded, according to the authors, to $176 \mathrm{~kg} \mathrm{ha}^{-1} \mathrm{~N}$.

The large reductions observed in MFPI and MFPE showed the importance of concern with nitrogen fertilization, even in a highly fertile soil.

The maximum lettuce yield was $23,744.48 \mathrm{~kg} \mathrm{ha}^{-1}$, at the $100 \mathrm{~kg} \mathrm{ha}^{-1}$ of $\mathrm{N}$ rate for lettuce and $195 \mathrm{~kg} \mathrm{ha}^{-1}$ of N for rocket (Figure 1C). Mantovani et al. (2005), in Jaboticabal, also observed second degree polynomial fit of lettuce cultivars including Veronica, with increase in the $\mathrm{N}$ rates and reported that $176 \mathrm{~kg} \mathrm{ha}^{-1} \mathrm{~N}$ resulted in the maximum yield for this cultivar. Pereira et al. (2003), in the region of Maringá-PR, also observed this quadratic performance of the lettuce response in yield in function of the $\mathrm{N}$ rates and the maximum yield obtained in the intercropping system was $10.4 \%$ less than that obtained in single cropping.

Considering only fertilization of 130 $\mathrm{kg} \mathrm{ha}^{-1} \mathrm{~N}$, as was applied to the lettuce in single cropping, the lettuce yield in intercropping would be $22,521.10 \mathrm{~kg}$ ha $^{-1}$ that would be equivalent to $94.8 \%$ the lettuce maximum yield (Figure 1C).

In addition to the possible partial use of the nitrogen fertilizer by the rocket, the possibility of rocket interfering in the lettuce in the presence of other production factors should also be considered especially space. Although Costa (2006) stated that lettuce yield in single cropping did not differ from lettuce intercropped with rocket sown on the same day as the lettuce transplant, the same condition as the present study, it cannot be denied that there is less 


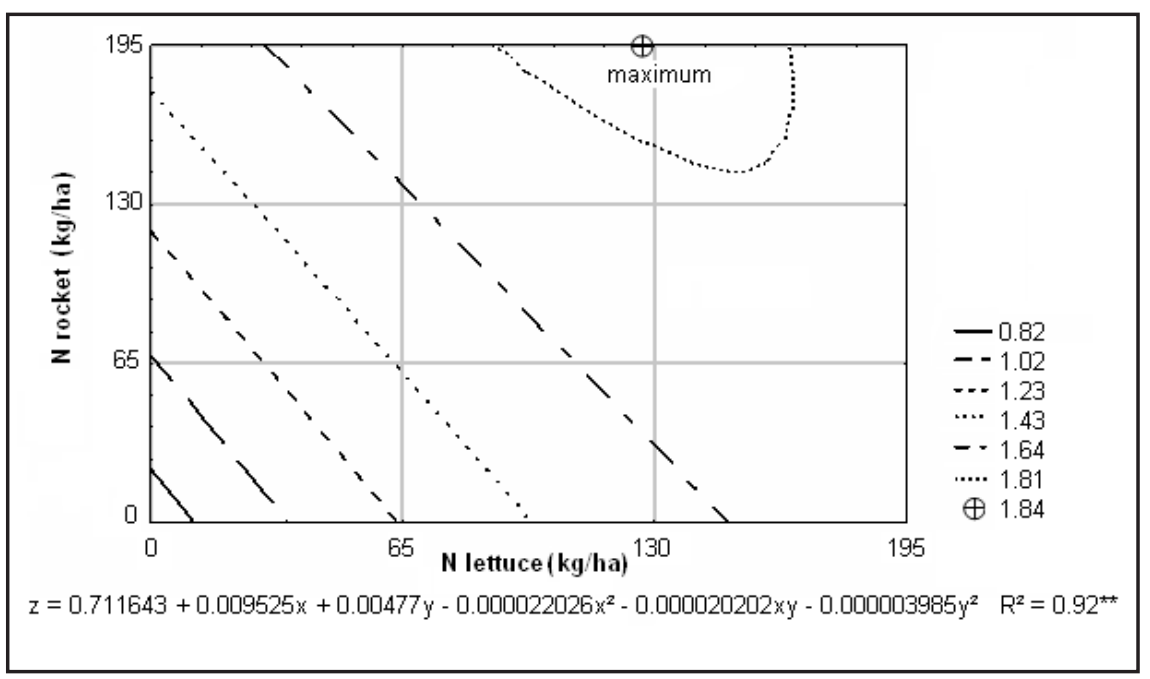

Figure 3. Response surface isolines for the land equivalent ratio (LER) for nitrogen rates in the fertilizers applied to lettuce and rocket under intercropping (isolinhas da superfície de resposta para o índice de eficiência de uso da área (EUA) em função das doses de nitrogênio nas adubações de alface e rúcula em consórcio). Jaboticabal, UNESP, 2008.

space for lettuce growth in intercropping systems. While lettuce in single cropping has $0.075 \mathrm{~m}^{2}$, in intercropping the area for its growth is restricted to at most, half of that available in single cropping.

Cecílio Filho et al. (2008) assessed chicory and rocket intercropping depending on the rocket sowing season in relation to chicory transplant. In the intercropping system, where the species are sown and transplanted on the same day, chicory reached the culture line of the rocket after the $33^{\text {rd }}$ day, of 40 days of the cycle.

To obtain $95 \%(22,557.26 \mathrm{~kg}$ $\mathrm{ha}^{-1}$ ) of the maximum yield found, lettuce nitrogen fertilization should be approximately $130 \mathrm{~kg} \mathrm{ha}^{-1}$ and nitrogen fertilizer need not be applied to the rocket. To obtain $90 \%\left(21,370.03 \mathrm{~kg} \mathrm{ha}^{-1}\right)$ of the maximum yield, $\mathrm{N}$ fertilization of approximately $100 \mathrm{~kg} \mathrm{ha}^{-1}$ should be applied to the lettuce, without $\mathrm{N}$ fertilization for the rocket (Figure 1C). Therefore, to produce 5 or $10 \%$ less the quantity of $\mathrm{N}$ supplied to the intercropping system should be reduced by 164 or $194 \mathrm{~kg} \mathrm{ha}^{-1}$ and in addition to be labor savings in rocket fertilization which becomes unnecessary in both cases. There are also costs such as labor for harvest, packing and transport that should be considered in the decision to aim for maximum or 90 or $95 \%$ of the maximum yield.

Not applying nitrogen fertilizer to the crops in intercropping resulted in a very sharp reduction in lettuce yield, about $50 \%$ of the maximum (Figure 1C).

There was significant difference for the rocket traits between the control (single cropping) and the factorial as observed for all the lettuce traits, the rocket yield in single cropping was greater than the mean of the intercropping system (Table 1).

Quadratic polynomial surface responses to nitrogen rates were fitted for rocket green matter and yield.

The maximum rocket green matter (RGM), 729.11 g plant $^{-1}$ was obtained in the intercropping system, with 195 $\mathrm{kg} \mathrm{ha}^{-1} \mathrm{~N}$ for the lettuce and $181 \mathrm{~kg}$ $\mathrm{ha}^{-1} \mathrm{~N}$ for the rocket (Figure 2A). This RGM was $20.2 \%$ greater compared to that obtained in single cropping, 606.44 g plant $^{-1}$ (Table 1). When nitrogen fertilization was not applied to either of the crops, the RGM decreased $70 \%$ from the maximum value obtained. Purquerio (2005) also observed an increase in the rocket green matter with increases in nitrogen rates for the crop, where the maximum RGM was obtained at the rate of $240 \mathrm{~kg} \mathrm{ha}^{-1}$.

It can be inferred that the rocket benefited much more from the fertilization applied to lettuce than the lettuce did from the fertilization for rocket. This was because if only the nitrogen fertilization carried out (intercropping) only for yield and, for the single cropping $\left(130 \mathrm{~kg} \mathrm{ha}^{-1}\right)$ was considered, the rocket RGM in intercropping would be a $463.52 \mathrm{~g}$ plant $^{-1}$, about $64 \%$ of the maximum obtained.

The great contribution of lettuce fertilization on rocket production can be observed in the analysis of the isolines in Figure 2A. For each kilogram of N supplied to the rocket or lettuce, the rocket RGM production was greater with the lettuce fertilization. For example, considering the rate of 130 $\mathrm{kg} \mathrm{ha}^{-1}$ of $\mathrm{N}$ and that in one hectare there are 19,200 and 26,400 meters of cropped rows of rocket and lettuce, respectively, for each $1 \mathrm{~g}$ of $\mathrm{N}$ supplied in the rocket and lettuce fertilization, the RGM production was $68.47 \mathrm{~g}$ and $122.85 \mathrm{~g}$, respectively.

The maximum rocket yield $\left(14,435.78 \mathrm{~kg} \mathrm{ha}^{-1}\right)$ was obtained with the combination of $195 \mathrm{~kg} \mathrm{ha}^{-1}$ of $\mathrm{N}$ for lettuce and $180 \mathrm{~kg} \mathrm{ha}^{-1}$ of $\mathrm{N}$ for rocket (Figure 2B). This maximum value was $9.8 \%$ less than that obtained by rocket in single cropping $\left(16,010.08 \mathrm{~kg} \mathrm{ha}^{-1}\right)$ (Table 1). Trani et al. (1994) reported a yield close the maximum obtained in the present study, with a $\mathrm{N}$ rate of 188 $\mathrm{kg} \mathrm{ha}^{-1}$ that produced $16,390 \mathrm{~kg} \mathrm{ha}^{-1}$.

To obtain 95\% $\left(13,713.19 \mathrm{~kg} \mathrm{ha}^{-1}\right)$ of the maximum rocket yield, among many combinations, there is $163 \mathrm{~kg} \mathrm{ha}^{-1}$ of $\mathrm{N}$ for lettuce and $107 \mathrm{~kg} \mathrm{ha}^{-1}$ of $\mathrm{N}$ for rocket. For $90 \%\left(12,992.20 \mathrm{~kg} \mathrm{ha}^{-1}\right)$ of the maximum production, $169 \mathrm{~kg} \mathrm{ha}^{-1}$ of $\mathrm{N}$ would be necessary for lettuce and $38 \mathrm{~kg} \mathrm{ha}^{-1}$ of $\mathrm{N}$ for rocket (Figure 2B). Therefore a savings of 105 and 168 $\mathrm{kg} \mathrm{ha}^{-1}$ of $\mathrm{N}$ was obtained, adding the quantities of $\mathrm{N}$ that would not be applied to the two crops in the intercropping system, if it was chosen to obtain 95 and $90 \%$ of maximum yield, respectively, compared to the $\mathrm{N}$ rates necessary to maximize yield.

Without nitrogen fertilization for either crop, the rocket yield decreased by $70 \%$ compared to the maximum yield obtained (Figure 2B). Significant reductions in rocket yield were also reported by Trani et al. (1994) and Purquerio (2005). In the absence of nitrogen fertilization the crop yield decreased, respectively, by $75.6 \%$ and $54.7 \%$ from the maximum obtained. 
Quadratic polynomial surface responses to nitrogen doses were fitted for LER indices assessed.

The maximum LER was 1.84 (Figure 3) obtained with $127 \mathrm{~kg} \mathrm{ha}^{-1}$ of $\mathrm{N}$ for lettuce and $195 \mathrm{~kg} \mathrm{ha}^{-1}$ of $\mathrm{N}$ for rocket. According to Gonçalves (1982), a LER value over 1 indicates an effect of cooperation or compensation between the intercropped crops, with advantages for the intercropping system. Costa (2006) assessed lettuce and rocket intercropping in function of cropping season and the rocket sowing time in relation to the transplant of three lettuce cultivars and observed that the LER of the intercropping systems ranged from 1.08 to 2.02 , indicating that there was better use of the environmental resources and/or products, compared to the single cropping. Cecílio Filho et al. (2008) assessed the productive and economic viability of chicory and rocket intercropping depending on the season when the intercropping was established and also observed that all the intercropping systems assessed were shown to be viable from the point of view of the LER, ranging from 1.31 to 2.29 . Rocket has been used as a secondary crop in vegetable intercropping because it has a short cycle, low/short stand and erect growth. These characteristics interfere little in the main crop and sometimes not at all, resulting not only in spatial but also temporal complementariness. However, intercropping recommendation cannot be based only on the LER assessment, because this index does not consider the quality of the food produced but only the quantity per area.

When the intercropping system was fertilized with quantities of less than 68 $\mathrm{kg} \mathrm{ha}^{-1}$ of $\mathrm{N}$ for rocket and $35 \mathrm{~kg} \mathrm{ha}^{-1}$ of $\mathrm{N}$ for lettuce, the intercropping did not result in a LER greater than 1 (Figure 3).

When the single cropping lettuce fertilization was used in the intercropping system, that is, $130 \mathrm{~kg} \mathrm{ha}^{-1}$, the LER would be 1.58 , about $14.1 \%$ less than the maximum land efficiency rate. This would occur mainly because of the great reduction in the rocket yield (about 24\% of the maximum) because the loss for lettuce would be only $5.2 \%$.

Figures $1 \mathrm{C}$ and $2 \mathrm{~B}$, that represent the lettuce and rocket yield, respectively, and Figure 3 that represents the LER, show that the index was maximized with $\mathrm{N}$ rates for lettuce and rocket very close to those that resulted in the maximum lettuce yield.

The increase in the $\mathrm{N}$ rates for both the crops, in the intercropping system, resulted in increases in the lettuce and rocket green matter and yield and maximized the land efficiency ratio (1.84) at the rate of $127 \mathrm{~kg} \mathrm{ha}^{-1} \mathrm{~N}$ for lettuce and $195 \mathrm{~kg} \mathrm{ha}^{-1} \mathrm{~N}$ for rocket.

\section{ACKOWLEDGEMENTS}

The second author thanks CNPq for the scholarship awarded.

\section{REFERENCES}

AHMED AHH; KHALIL MK; AMAL MF. 2000. Nitrate accumulation, growth, yield and chemical composition of Rocket (Eruca vesicaria subsp. Sativa) plant as affected by NPK fertilization, kinetin and salicylic acid. ICEHM2000, Cairo University, Egito, p. 495-508.

BARROS JÚNIOR AP; BEZERRA NETO F; NEGREIROS MZ; OLIVEIRA EQ; SILVEIRA, LM; CÂMARA MJT. 2005. Desempenho agronômico do bicultivo da alface em sistemas consorciados com cenoura em faixa sob diferentes densidades populacionais. Horticultura Brasileira 23: 712-717.

CECÍLIO FILHO AB; MAYA. 2000. Crescimento e produtividade da cultura do rabanete em função da época de semeadura na consorciação com alface. Horticultura Brasileira 18: 533534.

CECÍLIO FILHO AB; COSTA CC; REZENDE BLA; LEEUWEN R. 2008. Viabilidade produtiva e econômica do consórcio entre as culturas da chicória e rúcula, em função da época de estabelecimento do consórcio. Horticultura Brasileira 26: 316-320.

CEYLAN O; MORDOGAN N; CAKICI H; YOLDAS F. 2002. Effects of different nitrogen levels on the yield and nitrogen accumulation in the rocket. Asian Journal of Plant Sciences 1: 23-27.

COSTA CC. 2006. Consórcio de alface e rúcula: aspectos produtivos e econômicos. Jaboticabal: UNESP-FCAV. 83p. (Tese doutorado).

COSTA CC; CECÍLIO FILHO AB; REZENDE BLA; BARBOSA JC; GRANGEIRO LC.
2007. Viabilidade agronômica do consórcio de alface e rúcula, em duas épocas de cultivo. Horticultura brasileira 25: 34-40.

EMBRAPA. 1999. Sistema brasileiro e classificação de solos. Rio de Janeiro: Embrapa Solos. 412p.

ENGELS C; MARSCHNER H. 1995. Plant uptake and utilization of nitrogen. In: BACON EP. Nitrogen fertilization in the environment. New York: Marcel Dekker. 41-71.

GONÇALVES SR. 1982. Consorciação de culturas: técnicas de análise e estudo da distribuição do LER. Brasília: UNB-FAV. 217p. (Tese mestrado).

LÉDO FJS; CASALI VWD; MOURA WM; PEREIRA PRG; CRUZ CD. 2000. Eficiência nutricional do nitrogênio em cultivares de alface. Revista Ceres 47: 273-285.

MANTOVANI JR; FERREIRA ME; CRUZ MCP. 2005. Produção de alface e acúmulo de nitrato em função da adubação nitrogenada. Horticultura Brasileira 23: 758-762.

OLIVEIRA, EQ; BEZERRA NETO F; NEGREIROS MZ; BARROS JÚNIOR AP. 2004. Desempenho agroeconômico de alface em sistema solteiro e consorciado com cenoura. Horticultura Brasileira 22: 671-834.

PEREIRA OCN; BERTONHAA; FREITAS PSL; GOLÇALVES ACA; REZENDE R; SILVAFF. 2003. Produção de alface em função de água e de nitrogênio. Acta Scientiarum Agronomy 25: 381-386.

PURQUERIO LFV. 2005. Crescimento, produção e qualidade de rúcula (Eruca sativa Miller) em função do nitrogênio e da densidade de plantio. Botucatu: UNESP-FCA. 119p (Tese mestrado).

RESENDE GM; ALVARENGA MAR; YURI JE; MOTA JH; SOUZA RJ; RODRIGUES JÚNIOR JC. 2005. Produtividade e qualidade pós-colheita da alface americana em função de doses de nitrogênio e molibdênio. Horticultura Brasileira 23: 976-981.

REZENDE BLA. 2004. Análise produtiva e rentabilidade das culturas de pimentão, repolho, rúcula, alface e rabanete em cultivo consorciado. Jaboticabal: UNESP-FCAV. 60p (Tese mestrado).

TRANI PE; GRANJA NP; BASSO LC; DIAS DCFS; MINAMI K. 1994. Produção e acúmulo de nitrato pela rúcula afetados por doses de nitrogênio. Horticultura Brasileira 12: 25-29.

TRANI PE; PASSOS FA; AZEVEDO FILHO JA. 1997. Alface, almeirão, chicória, escarola, rúcula e agrião d'agua. In: RAIJ B; CANTARELLAH; QUAGGIO JA; FURLANI AMC. Recomendação de adubação e calagem para o estado de São Paulo. Campinas. p. 168.

VANDERMEER JH. 1981. The interference production principle: an ecological theory for agriculture. BioScience 31: 361-4.

WILLEY RW. 1979. Intercropping: its importance and research needs. Part 1. Competition and yield advantages. Field Crops Abstract 32: $1-10$. 